\title{
Pengembangan Buku Ajar Sejarah Fisika Berbasis Higher Order Thingking Skill (HOTS)
}

\author{
I Wayan Gunada*, Syahrial Ayub, Aris Doyan, Ni Nyoman Putu Sri Verawati, Hikmawati \\ Program Studi Pendidikan Fisika, Universitas Mataram \\ *Email: wayan_gunada@unram.ac.id
}

Received: 1 Juni 2021;

Accepted: 30 Juni 2021;

Published: 30 Juni 2021

DOI: http://dx.doi.org/10.29303/jpft.v7i1.2767

\begin{abstract}
This study aims to develop and produce a physics history textbook based on higher order thinking skills (HOTS). This research was a development research which consists of four stages, namely: the determination stage, design, development, and dissemination. The success of the indicators of this research were seen from the feasibility of the developed textbooks. Physics history textbook based on higher order thinking skills was categorized as good and suitable for use, in terms of content, presentation, and language feasibility. Meanwhile, in terms of textbook effectiveness, it was measured by the impact of increasing students' higher order thinking skills as seen from the increase in N-gain. The student's high-order thinking skills had increased with $N$ gain 0.4 (moderate category). This shows that the textbooks that have been developed are feasible and effective in terms of the ability to increase higher-order thinking skills (HOTS).
\end{abstract}

Keywords: Physics History; Higher Order Thinking Skill

\section{PENDAHULUAN}

Kemampuan berpikir tingkat tinggi adalah salah satu kemampuan yang dibutuhkan pada abad 21. Kemampuan berpikir merupakan keterampilan yang harus ditumbuhkembangkan bagi peserti didik agar mampu berdaya saing di abad 21 (Bahtiar, 2018). Berpikir merupakan suatu aktivitas mental yang berkaitan dengan kesadaran dan proses dalam memahami, menalar, mengidentifikasi suatu permasalahan untuk mendapatkan solusi permasalahan. Kemampuan berpikir dapat dibedakan menjadi berpikir kreatif dan berpikir kritis. Kedua jenis kemampuan berpikir ini disebut kemampuan berpikir tingkat tinggi.

Kemampuan berpikir tingkat tinggi merupakan aspek penting dalam pengajaran dan pembelajaran. Kemampuan berpikir seseorang dapat mempengaruhi kemampuan pembelajaran, kecepatan dan efektivitas pembelajaran. Oleh karena itu, dalam proses pembelajaran sebaiknya memperhatikan kemampuan berpikir peserta didik. Peserta didik yang dilatih untuk berpikir menunjukkan dampak positif pada pengembangan pendidikan mereka.

Proses pembelajaran pada hakekatnya untuk mencapai tujuan pembelajaran. Tujuan pembelajaran pada ranah kognitif menurut Bloom merupakan segala aktivitas pembelajaran menjadi 6 tingkatan sesuai dengan jenjang terendah sampai tertinggi yang terbagi atas lower-order thinking skills (LOTS) dan higher-order thinking skills (HOTS) (Ariyana, et al., 2018). Lower-order thinking skills meliputi: mengingat (C1), memahami (C2), dan mengaplikasikan (C3).

Sedangkan higher-order thinking skills (HOTS) meliputi : menganalisis (C4), menilai/mengevaluasi (C5), dan mencipta/mengkreasi (C6).

Akan tetapi yang terjadi selama ini yang menyebabkan lemahnya kualitas pembelajaran, yaitu berakar dari lemahnya proses pembelajaran yang tidak mendorong peserta didik untuk berpikir (Ariyati, 2010). Proses pembelajaran akan tercapai secara optimal apabila tersedia bahan ajar yang cukup, strategi pembelajaran yang tepat, dan sistem evaluasi yang baik (Gunada et al., 
2016). Bahan ajar adalah segala bentuk bahan yang digunakan untuk membantu guru/instruktur dalam melaksanakan proses pembelajaran di kelas (Nurhidayati et al., 2017). Bahan yang dimaksud bisa berupa bahan tertulis maupun tidak tertulis. Salah satu jenis bahan ajar adalah buku ajar.

Akan tetapi, kenyataannya berdasarkan hasil observasi pada proses perkuliahan sejarah fisika belum memiliki buku ajar yang memadai dan proses perkuliahan hanya mengulas tokoh-tokoh fisika tentang otobiografi dan temuannya. Pada proses selanjutnya mahasiswa belum bisa mengklasifikasikan atau menggolongkan tokoh fisika tersebut berkembang sesuai dengan periodisasinya. Kenyataan ini, mahasiswa masih belum bisa menganalisis dan mengevaluasi perkembangan sejarah fisika. Fisika telah berperan dalam membentuk pemikiran manusia dan berkontribusi ke peradaban yang modern. Melalui pengajaran fisika dengan memperkenalkan sejarah dan filsafat sains dapat menjembatani pengetahuan dan mengkonstruk pengetahuan tentang konsep fisika (Sinensis, 2017).

Oleh sebab itu mahasiswa perlu dilatih untuk mengambil keputusan yang tepat, yang dituangkan dalam buku ajar. Buku ajar merupakan perangkat yang ampuh digunakan dalam proses pembelajaran untuk meningkatkan kemampuan seseorang untuk mengingat (Angraeni et al, 2019).

Penelitian terkait dengan pengembangan buku ajar sejarah fisika telah dilakukan Angraeni et al., (2019), yang mengembangkan buku ajar sejarah fisika berbasis ICT. Hertiavi dan Sopacua (2020) pengembangan perangkat perkuliahan daring bermuatan pendidikan karakter pada matakuliah sejarah fisika dapat meningkatkan keaktifan dan hasil belajar mahasiswa. Berdasarkan penelitian yang telah dilakukan, pengembangannya belum berorientasi untuk meningkatkan kemampuan berpikir mahasiswa. Hight order thinking peserta didik meningkat, sehingga dapat membedakan gagasan secara jelas, berargumen dengan baik, memecahkan masalah, mengkonstruksi penjelasan, berhipotesis dan memahami hal-hal kompleks menjadi lebih jelas (Dinni, 2018).

Bertitik tolak pemikiran untuk meningkatkan kemampuan berpikir mahasiswa, memudahkan dosen untuk mengajar, dan untuk mencapai tujuan pembelajaran yang diharapkan maka dikembangkanlah buku ajar sejarah fisika berbasis higher order thinking skill (HOTS).

\section{METODE PENELITIAN}

Penelitian ini termasuk jenis penelitian pengembangan pendidikan (Educational Research and Development) yang digunakan untuk mengembangkan dan memvalidasi produk-produk pendidikan. Produk yang dimaksud berupa buku ajar sejarah fisika berbasis higher order thinking skill (HOTS). Tahapan penelitian ini terdiri atas 4 tahap. Pertama, tahap define dilakukan studi analisis kurikulum program studi, analisis kebutuhan buku ajar sejarah fisika, analisis materi, analisis karakteristik mahasiswa dan analisis capaian pembelajaran mata kuliah (CPMK) yang disesuakan dengan capaian lulusan (CPL). Tahap kedua yaitu tahap design dirancang buku ajar sejarah fisika berbasis higher order thinking skill (HOTS). Tahap ini dirancang pembuatan buku ajar yang disesuaikan dengan rancangan pembelajaran semester (RPS).

Tahap ketiga, yaitu develop. Tahap ini menghasilkan buku ajar sejarah fisika berbasis higher order thinking skill (HOTS), yang sudah divalidasi.Tahap keempat, tahap disseminate,yang merupakan tahap penggunaan buku ajar sejarah fisika pada skala yang lebih luas.

Instrumen yang digunakan untuk mengumpulkan data dalam penelitian ini berupa lembar validasi ahli, lembar uji 
kelompok kecil mahasiswa, dan instrumen tes kemampuan berpikir tingkat tinggi yang indikatornya menganalisis, menilai/mengevaluasi, dan mengkreasi. Uji ahli dilakukan kalangan akademisi. untuk mengetahui kualitas buku ajar terutama menyangkut aspek - aspek ketatabahasaan, kemenarikan, materi dan indikator.

Lembar angket untuk validasi ahli menggunakan skala 1 sampai 4. Analisis kelayakan buku ajar menggunakan rentang skor sebagai berikut:

Keterangan:

$$
P=\frac{\sum X}{\sum S M I} \times 100 \%
$$

$\begin{array}{ll}P & =\text { persentase } \\ \sum X & =\text { jumlah skor yang dicapai } \\ \sum S M I & =\text { skor maksimum ideal }\end{array}$

Tabel 1. Nilai Persentase Kelayakan Buku Ajar

\begin{tabular}{ccc}
\hline No. & Interval & Kriteria \\
\hline 1. & $80 \%-100 \%$ & Sangat baik/Sangat layak \\
2. & $60 \%-79 \%$ & Baik/Layak \\
3. & $50 \%-59 \%$ & Kurang baik/Kurang \\
& & layak \\
4. & $\leq 50 \%$ & Tidak baik/tidak layak \\
\hline
\end{tabular}

Indikator keberhasilan dari penelitian pengembangan ini meliputi:

1. Keberhasilan dari buku ajar sejarah fisika yang telah dikembangkan, jika buku ajar yang telah dikembangkan dalam kategori baik/ layak.

2. Mahasiswa dapat menggunakan buku ajar sejarah fisika berbasis higher order thinking skill (HOTS) yang telah dikembangkan sehingga kemampuan berpikir meningkat. Peningkatannya dilihat dengan nilai $\mathrm{N}$-gain (normalized gain). Peningkatan kemampuan berpikir tingkat tinggi (HOTS) mahasiswa dapat ditentukan dengan menggunakan persamaan berikut :

$$
\text { std }<g \geq=\frac{\bar{X}_{\text {sesudah }}-\bar{X}_{\text {sebelum }}}{\bar{X}_{\text {maks }}-\bar{X}_{\text {sebelum }}}
$$

Keterangan:

$\bar{X}_{\text {sesudah }}=$ skor post-test

$$
\begin{aligned}
& \bar{X}_{\text {sebelum }}=\text { skor } \text { pre-test } \\
& \bar{X}_{\text {maks }}=\text { skor maksimum }
\end{aligned}
$$

Berdasarkan nilai $\mathrm{N}$-gain (normalized gain), kemudian hasilnya dikelompokkan sesuai dengan Tabel 2.

Tabel 2. Kriteria N-gain (normalized gain)

\begin{tabular}{cc}
\hline Nilai $<\mathrm{g}>$ & Interpretasi \\
\hline $0,70<\mathrm{g}<1,00$ & Tinggi \\
$0,30<\mathrm{g}<0,70$ & Sedang \\
$0,0<\mathrm{g}<0,30$ & Rendah \\
$\mathrm{g}=0,00$ & Tidak Terjadi Peningkatan \\
$-1,00 \leq \mathrm{g}<0,00$ & Terjadi Penurunan \\
\hline & (Nirmalasari, et al., 2016)
\end{tabular}

3. Aktivitas mahasiswa dalam proses pembelajaran meliputi aspek aktivitas visual, menulis, emosional, dan aktivitas lisan.

\section{HASIL DAN PEMBAHASAN Tahap Define}

Hasil penelitian pada tahap Define dilakukan studi pendahuluan yang terdiri dari analisis kurikulum Program Studi Pendidikan Fisika, analisis peserta didik (mahasiswa) diperoleh gambaran bahwa mahasiswa cenderung memperoleh gambaran tentang sejarah fisika, hanya dari otobiografi tokoh dan temuannya. Berdasarkan analisis capaian pembelajaran mata kuliah (CPMK) sejarah fisika, diperoleh gambaran bahwa mahasiswa diharapkan dapat menganalisis, mengevaluasi, dan mengkreasi perkembangan ilmu fisika sesuai dengan periodisasi perkembangan sejarah fisika. Kemudian capaian pembelajaran (learning outcomes): mahasiswa diharapkan mampu menganalisis periodisasi perkembangan ilmu fisika. Rumusan tujuan pembelajaran pada matakuliah sejarah fisika yang ingin dicapai antara lain:

1) Mengetahui periodisasi perkembangan ilmu fisika beserta tokoh-tokohnya yang terlibat pada periode tersebut. 
2) Untuk menambah wawasan dan khasanah tentang perkembangan ilmu fisika.

3) Untuk mengetahui karakteristik atau ciri khas perkembangan ilmu fisika dari zaman kuno sampai zaman sekarang.

\section{Tahap Design}

Pada tahap ini, di hasilkan draf buku ajar sejarah fisika dan disertai dengan petunjuk instruksional. Kekhususan dari buku ajar ini, lebih banyak diisi materi tentang tokoh dan pemikiran, serta temuannya tentang ilmu fisika. Rincian pokok bahasan buku ajar yang dihasilkan meliputi:

1) Bab I Periode Pertama (Zaman Kuno$1500 \mathrm{M}$ )

Deskripsi: llmu fisika pada periode pertama mempunyai ciri atau karakteristik spekulatif dan berfilsafat tentang alam, artinya kemunculan ilmu di adobsi dari gejala-gejala alam.

2) Bab II Periode Kedua (1550 - 1800 M)

Deskripsi: Periode kedua atau periode abad ke 17 sampai abad ke 18, perkembangan ilmu fisika mempunyai karakteristik pengembangan dan pemantapan metode eksperimental. Sejumlah tokoh mengungkapkan teori dengan eksperimennya masing-masing. Pada periode ini merupakan suatu periode yang dapat mengatasi dogma, dan ketidaktoleransian agama untuk bisa mendapatkan pengakuan internasional.

3) Bab III Periode Ketiga atau Era Fisika Klasik (1800 - $1890 \mathrm{M})$

Deskripsi: Periode ketiga atau era fisika klasik perkembangannya terjadi pada abad ke 19. Keberhasilan yang dicapai oleh Galileo dan Newton pada abad ke tujuh belas, banyak fisikawan merasa bahwa prinsip-prinsip dasar fisika yang mendasari kerja alam material telah habis ditemukan. Pandangan atomisasi, interaksi antar jarak, determinisme, tampaknya merupakan gagasan yang tidak akan pernah dirobohkan.
Sesungguhnya massa dua puluh tahun mengikuti periode Galileo dan Newton, sumbangan para ilmuan hanyalah menerapkan prinsip yang telah dianggap benar dengan menggunakan matematika baru yang ditemukan oleh Newton

4) Bab IV Periode Keempat (1890 - 1925)

Deskripsi: Munculnya penemuaan teori kuantum dan teori relativitas khusus, yang akan nantinya akan mendasari perkembangan fisika modern. Tokoh-tokoh yang meniti kariernya pada periode iniantara lain: Nikola Tesla, J.J. Thomson, Plack, Marie Curie, Antonie Henri Bacquerel, Lorentz, Milikian, dan Louis Victor the Broglie.

5) Bab V (1925-Sampai sekarang)

Deskripsi: Perkembangan ilmu pengetahuan pada periode ini memunculkan tokoh-tokoh dengan ide dan pemikirannya yang cemerlang seperti : Werner Heisenberg, Thomson, Enrico Fermi, Athur Holly Compton, Schrodinger, Juliot Curie dan Irene Curie, Hans Daniel Jensen. Pada periode ini, juga di bahas pemenang piala Nobel dalam bidang Fisika

\section{Tahap Develop}

Pada tahap ini, buku ajar yang telah dibuat dilakukan pengujian pada 2 tahap yaitu: 1) uji validitas dan 2) uji efektifitas produk. Uji efektifitas produk dilihat dari hasil peningkatan kemampuan berpikir tingkat tinggi mahasiswa dan respon mahasiswa.

1) Uji Validitas Buku Ajar Sejarah Fisika

Buku ajar yang telah dibuat, kemudian direveiw melalui angket yang berisikan pernyataan dengan skala penilaian 1 sampai 4 yang kelompokkan dalam tiga aspek yaitu (1) aspek kelayakan isi, (2) penyajian, dan (3) kebahasaan. Berdasarkan penilaian dari dua reviewer, yang dinilai dari segi kelayakan isi, penyajian dan kebahasaan buku ajar sejarah fisika yang telah dibuat, terlihat bahwa komponen kelayakan isi memberikan 
rata-rata skor $12,5(78,13 \%)$ yang termasuk dalam kategori baik/layak, komponen penyajian memperoleh skor rata-rata 39 $(81,24 \%)$ dan dikategorikan sangat baik/sangat layak, sedangkan dari segi kebahasaan memperoleh skor rata-rata 30,5 (76,25\%) dikategorikan baik/layak. Secara keseluruhan, hasil penilaian reviewer I dan reviewer II terhadap buku ajar sejarah fisika ditinjau dari aspek kelayakan isi, penyajian, dan kebahasaan diperoleh skor 82 dan jika diprosentase menjadi 78,84\%. Hal ini menunjukan bahwa dari segi kelayakan, buku ajar sejarah fisikaa dikategorikan baik dan layak digunakan.

2) Implementasi (Uji Efektivitas Buku Ajar)

Setelah tahap validasi, selanjutnya buku ajar sejarah fisika diujicobakan untuk mengetahui tingkat efektifitas. Uji coba dilakukan pada perkuliahan sejarah fisika pada mahasiswa Program Studi Pendidikan Fisika FKIP Unram khususnya kelas B Untuk mengetahui tingkat efektifitas prototipe buku yang telah dikembangkan, maka buku tersebut diuji cobakan dan diamati dampak aktivitas mahasiswa dan dampak kemampuan berpikir tingkat tinggi (HOTS). Dampak kemampuan berpikir tingkat tinggi dilihat dari hasil skor pretest dan skor posttest, seperti yang terlihat pada Gambar 1.

Berdasarkan Gambar 1. dari tiga indikator kemampuan berpikir tingkat tinggi yang diukur, ketiganya mengalami peningkatan, terlihat dari nilai pretest dan posttest pada masing-masing indikator tersebut. Secara keseluruhan nilai rata-rata kemampuan berpikir tingkat tinggi (HOTS) diperoleh nilai pretest 75,67 dan skor rata-rata posttest sebesar 85,00. Sedangkan indikator yang mengalami peningkatan paling besar adalah mengkreasi/mencipta, dan yang paling rendah pada indikator menganalisis.

Untuk melihat peningkatan kemampuan berpikir tingkat tinggi, maka di bawah ini disajikan data perhitungan $\mathrm{N}$ gain pada tiaptiap indikator yang diukur.

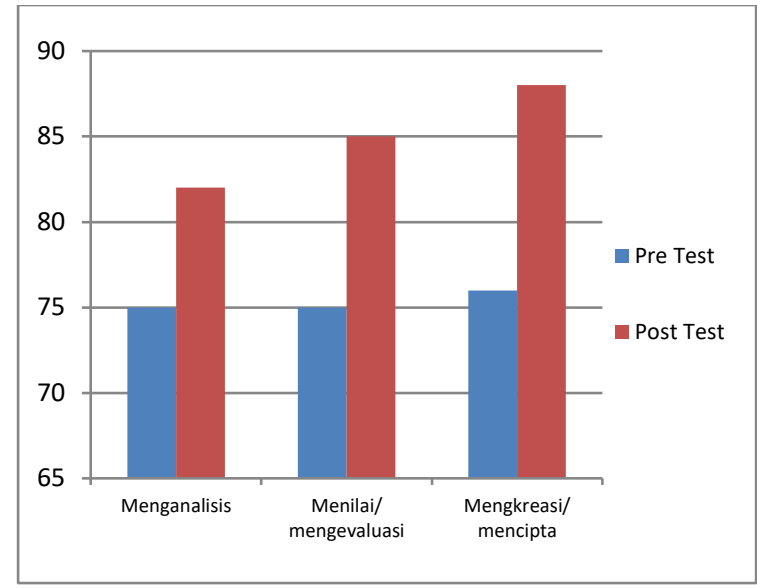

Gambar 1. Hasil Pretest dan Posttest Per Indikator Kemampuan Berpikir Tingkat Tinggi (HOTS)

Terdapat 3 (tiga) indikator kemampuan berpikir tingkat tinggi yang diukur pada proses pembelajaran matakuliah sejarah fisika. Indikator pertama dihasilkan $\mathrm{N}$-gain sebesar 0.3 (kategori sedang), $N$-gain pada indikator kedua sebesar 0.4 (katagori sedang) dan $N$ - gain pada indikator ketiga 0.5 (katagori sedang). Dapat disimpulkan bahwa rata-rata $\mathrm{N}$-gain pada ketiga indikator tersebut sebesar 0,4 dan kategori sedang. Hasil N-gain pada indikator menganalisi dan $\mathrm{N}$-gain tertinggi pada indikator mengkreasi/mencipta.

Tabel 3. Hasil Uji N-Gain Indikator Kemampuan Berpikir Tingkat Tinggi yang Diukur

\begin{tabular}{cccc}
\hline No & Indikator & N -Gain & Interpretasi \\
\hline 1. & Menganalisis & 0,3 & Sedang \\
2. & $\begin{array}{c}\text { Menilai/ } \\
\text { mengevaluasi }\end{array}$ & 0,4 & Sedang \\
3. & $\begin{array}{c}\text { Mengkreasi/ } \\
\text { mencipta }\end{array}$ & 0,5 & Sedang \\
& Rata-rata & 0,4 & Sedang \\
\hline
\end{tabular}

Secara keseluruhan N-gain kemampuan berpikir tingkat tinggi (HOTS) berada pada kategori sedang. Hal ini sejalan dengan hasil penelitian Sitinjak, (2020) bahwa kemampuan mahasiswa dalam menyelesaikan soal HOTS pada kuliah fisika umum berada dalam kategori cukup dengan pencapaian $51 \%$ sampai $75 \%$, yang diklasifikasikan tingkat 
menganalisis (C4) diperoleh prosentase $60 \%$ (cukup), mengevaluasi (C5) 50\% kategori cukup dan mencipta (C6) prosentase 55\% kategori cukup.

Hasil peningkatan kemampuan berpikir tingkat tinggi yang paling besar adalah mengkreasi/mencipta (C6), didasarkan pada kemampuan mahasiswa dapat mengumpulkan referensi tokoh-tokoh fisika dan dapat mengklasifikasikan berdasarkan periodisasi perkembangan sejarah fisika. Sedangkan kemampuan menganalisis peningkatannya paling rendah, ternyata kemampuan untuk mengkorelasikan dan menyimpulkan perkembangan karakteristik pada masing-masing periodisasi sejarah fisika belum optimal. Hasil penelitian ini berbeda dengan penelitian Nurhayati dan Angraeni, L., (2017), yang menganalisis kemampuan berpikir tingkat tinggi mahasiswa dalam menyelesaikan soal konsep optika, dan hasilnya kemampuan menganalisis paling besar (C4) sebesar 68,42\% dan kemampuan mencipta (C6) paling kecil sebesar 53,51\%. Akan tetapi secara keseluruhan persentase mahasiswa yang memiliki kemampuan berpikir tingkat tinggi kategori cukup sebesar $42,11 \%$.

3) Akitvitas Mahasiswa Pada Proses Pembelajaran

Hasil aktivitas mahasiswa selama proses pembelajaran dengan total jumlah mahasiswa pada kelas B sebanyak 25 orang. Aspek aktivitas yang diamati, meliputi aspek aktivitas visual, menulis, emosional, dan aktivitas lisan. Aktivitas tersebut diamati, dari lima kali pertemuan perkuliahan. Secara keseluruhan prosentase skor rata-rata (SR) aktivitas rata-rata mahasiswa yang terlihat selama proses pembelajaran setelah menggunakan buku ajar sejarah fisika sebesar 73,59\%, termasuk dalam kategori baik. Hal ini dapat disimpulkan bahwa aktivitas mahasiswa yang belajar dengan menggunakan buku ajar sejarah fisika dapat dikategorikan baik.

\section{PENUTUP}

Berdasarkan hasil penelitian dan pembahasan, dapat disimpulkan bahwa, buku ajar sejarah fisika berbasis higher order thinking skill dikategorikan baik/layak digunakan, ditinjau dari segi kelayakan isi, penyajian, dan kebahasaan. Uji efektivitas buku ajar memperoleh nilai rata-rata $N$-gain 4,0 dari ketiga indikator kemampuan berpikir tingkat tinggi (HOTS) yang diukur dan dikategorikan sedang. Aktivitas rata-rata mahasiswa yang diamati meliputi aktivitas visual, menulis, emosional, dan aktivitas lisan. Aktivitas proses pembelajaran setelah menggunakan buku ajar sejarah fisika sebesar 73,59\%, termasuk dalam kategori baik. Hal ini dapat disimpulkan bahwa aktivitas mahasiswa yang belajar dengan menggunakan buku ajar sejarah fisika dapat dikategorikan baik.

\section{UCAPAN TERIMAKASIH}

Ucapan terimakasih kepada Lembaga Penelitian dan Pengabdian Masyarakat Universitas Mataram yang telah membantu penulis dalam penelitian maupun publikasi ilmiah.

\section{REFERENSI}

Angraeni, L., Boisandi, Matsun. (2019). Pengembangan Buku Ajar Sejarah Fisika Berbasis ICT. Kappa Journal,3(2),126-133. from DOI: 10.29408/kpj.v3i2.1714

Ariyana, Y., Pudjiastuti, A., Bestari, R., Zamroni. (2018). Buku Pegangan Pembelajaran Berorientasi Pada Keterampilan Berpikir Tingkat Tinggi. Direktorat Jendral Guru dan Tenaga Kependidikan Kementerian Pendidikan dan Kebudayaaan.

Ariyati, E. (2010). Pembelajaran Berbasis Praktikum Untuk Meningkatkan 
Kemampuan Berpikir Kritis Mahasiswa. Jurnal Matematika dan IPA. 1(2),10-29. From http://dx.doi.org/10.26418/jpmipa.v1i2. 194

Bahtiar. (2018). Pengembangan Bahan Ajar Fisika Dasar Berbasis Model Pembelajaran 3Pe Untuk Meningkatkan Kemampuan Berpikir Kritis Mahasiswa Program Studi Tadris Fisika. Jurnal Pendidikan Fisika dan Teknologi,4(2), 176-184, from http://dx.doi.org/10.29303/jpft.v4i2.78

Dinni, H.N. (2018) HOTS (High Order Thinking Skills) dan Kaitannya dengan Kemampuan Literasi Matematika.Prisma, Prosiding Seminar Nasional Matematika, Unnes.

Gunada, IW., Rokhmat, J., Hikmawati, Wahyudi. (2016). Pengembangan Bahan Ajar Fisika Matematika Berbasis Self Directed Learning untuk Meningkatkan Kemampuan Pemecahan Masalah. Laporan Penelitian. Lemlit Universitas Mataram.

Hertiavi, M.A., \& Sopacua, V. (2020) Pengembangan Kelas Daring Bermuatan Pendidikan Karakter Pada Matakuliah Sejarah Fisika.Biopendik, 7(1), 39-48, from https://doi.org/10.30598/biopendixvol7 issuelpage 39-48

Nurhayati, \& Anggraeni, L. (2017). Analisis Kemampuan Berpikir Tingkat Tinggi Mahasiswa (Higher Order Thinking) dalam Menyelesaikan Soal Konsep Optika melalui Model Problem Based Learning. Jurnal Penelitian \& Pengembangan Pendidikan Fisika, 3(2), 119-126, from https://doi.org/10.21009/1.03201

Nurhidayati, S., Tayeb, T., Baharudin. (2017). Pengembangan Bahan Ajar Matematika Berbasis Masalah Untuk Memfasilitasi Kemampuan Penalaran Pada Pokok Bahasan Perbandingan Kelas VII MTSN Model Makasar. Jurnal Matematika dan Pembelajaran, 5(2), 236-250 from http://journal.uin-
alauddin.ac.id/index.php/Mapan/article/ view/3530

Nirmalasari, Santiani, \& Rohmadi, M. (2016) Penerapan Model Pembelajaran Learning Cycle Terhadap Keterampilan Proses Sains dan Hasil Belajar Siswa Pada Getaran Harmonis. Edusains, 4(2), 74-94, from http://e-journal.iainpalangkaraya.ac.id/index.php/edusains/ article/view/511

Sinensis, A.R. (2017). Sejarah dan Filsafat Sains Sebagai Pendekatan dalam Pengajaran Fisika Pada Konsep Archimedes. Jurnal Inovasi Pendidikan Fisika dan Riset Ilmiah, 1(1), 23-28, from https://doi.org/10.30599/jipfri.v1i1.120

Sitinjak, E.K. (2020) Analisis Kemampuan Berpikir Tingkat Tinggi (High Order Thingking Skills) Mahasiswa dalam Memecahkan Masalah Materi Suhu dan Kalor Pada Matakuliah Fisika Umum T.A 2019/2020. Jurnal Ilmiah Simantek, 4(3), 95-102, from https://simantek.sciencemakarioz.org/in dex.php/JIK/article/view/169 